\title{
Predictive value of two polymorphisms in ABCB1, rs1045642 and rs1128503, in prognosis following taxane- containing chemotherapy: A meta-analysis
}

\section{Quanyao Chen}

Women and Children's Hospital, School of Medicine, Xiamen University https://orcid.org/0000-0003-4408-2565

Wanlong Lin

Women and Children's Hospital, School of Medicine, Xiamen University

Jianhui Yang

Women and Children's Hospital, School of Medicine, Xiamen University

Min Lin

Women and Children's Hospital, School of Medicine, Xiamen University

Xiuxian Lin

Women and Children's Hospital, School of Medicine, Xiamen University

Jiangfeng Huang

Xiamen Key Laboratory of Otolary of Otolartngology Head and Neck Surgery

\section{Yiyin Weng}

Women and Children's Hospital, School of Medicine, Xiamen University

Jujiang Guo

Women and Children's Hospital, School of Medicine, Xiamen University

Yao Chen ( $\nabla$ chenquanyao1@gmail.com )

\section{Research article}

Keywords: Paclitaxel; taxane; ABCB1; progression-free survival; overall survival

Posted Date: March 11th, 2020

DOI: https://doi.org/10.21203/rs.3.rs-16731/v1

License: (c) (i) This work is licensed under a Creative Commons Attribution 4.0 International License. Read Full License 


\section{Abstract}

Background: Although taxane-containing chemotherapy is widely used to treat solid tumors, genetic polymorphisms can influence the chemotherapeutic response. This meta-analysis was conducted to determine the correlation between two polymorphisms in ABCB1, rs1045642 and rs1128503, and survival of patients administered taxanecontaining chemotherapy. Methods: PubMed, Web of Science, Embase, Wanfang database, VIP database, and China National Knowledge Infrastructure database were used to obtain articles published up to August 2019 describing the association between the ABCB1 rs1045642 and rs1128503 polymorphisms and survival. A meta-analysis was conducted using R 3.6.1 software to determine the pooled hazard ratio (HR) and 95\% confidence intervals $(95 \% \mathrm{Cl})$. Furthermore, publication bias was assessed, and sensitivity analysis was performed to validate the analysis. Results: Fifteen studies involving 3320 patients were included in the meta-analysis. The summary results showed that the effect of the C1236T polymorphism on progression-free survival remained significant in the heterozygote model (HR 0.81; 95\% Cl: 0.67-0.98) and homozygote model (HR 0.71; $95 \% \mathrm{Cl}: 0.58-0.88)$. Compared to the C1236 TT phenotype, the CC genotype was associated with a poor overall survival (HR 0.72; 95\% Cl: 0.53-0.97). Finally, subgroup analysis suggested that different areas, tumor types, and treatment regimens influence patient survival. Conclusions: Patients who are ABCB1 rs1045642 and rs1128503 T gene carriers show a survival benefit with taxane-containing chemotherapy.

\section{Background}

Taxane is widely used to treat different types of solid tumors, such as breast cancer, ovarian cancer, some head and neck cancers, and lung cancer. Taxane can disrupt the dynamic balance between microtubules and tubulin dimers to promote tumor cell apoptosis and has anti-tumor effects. Clinical studies have shown that the toxicity and efficacy of taxane vary widely and exhibit inter-individual differences, leading to large variations in individual prognosis. An increasing number of studies have indicated that genetic factors such as single-nucleotide polymorphisms (SNPs) play an important role in individual differences in the prognosis of patients administered taxane-containing chemotherapy [1-4].

Several gene polymorphisms have been shown to affect the activity of taxane. The most common is the adenosine triphosphate-binding cassette transporter $\mathrm{B}$ subfamily member 1 ( $A B C B 1$ ) gene, also known as multidrug resistance gene 1, which is located in humans on the long arm of chromosome 7. This gene encodes P-glycoprotein (P-gp), which can transport a variety of chemical drugs and function as a transmembrane osmotic pump [5]. When P-gp activity increases, antitumor drugs that enter the cell can be actively pumped out of the cell [6-8]. Because of this increased outflow and/or decreased inflow, antitumor drugs in tumor cells show insufficient accumulation, reducing their efficacy, which is the key mechanism of chemotherapy resistance $[9,10]$. P-gp is involved in the transport of multiple antitumor drugs including paclitaxel and docetaxel [11]. SNPs may affect drug sensitivity and drug resistance through various mechanisms $[12,13]$, such as altering the expression levels, stability, degradation, substrate specificity, activity, and/or role of transporters [14-17], which can affect prognosis [18].

The association between $A B C B 1$ polymorphisms and the prognosis of patients following taxane-containing chemotherapy has been explored in several studies. However, the results are inconclusive and studies showed contrasting results and weak data [19-24]. Given the importance of $A B C B 1$ polymorphisms, information obtained by doctors, pharmacists, and statisticians was used to perform this meta-analysis, systematically integrating the current pharmacogenetic literature to obtain more credible evidence. This study was conducted to assess the association between rs1045642 (C3435T) and rs1128503 (C1236T) and the prognosis of patients administered taxanecontaining chemotherapy as well as to provide a basis for clinical personalized medicine. 


\section{Methods}

\subsection{Data sources, search strategy, and selection criteria}

This review was performed according to the Meta-analysis of Observational Studies in Epidemiology guidelines issued in 2000 [25] (PROSPERO Registration Number: CRD42019128195). Two authors systematically searched electronic databases to identify all studies related to the impact of rs1045642 and rs1128503 on the overall survival (OS) and progression-free survival (PFS) of patients receiving taxane-based chemotherapy. The electronic databases PubMed, Embase, Web of Science, Cochrane library, Chinese National Knowledge Infrastructure, Wanfang, and Weipu were searched from the time of library construction to August 2019 with the following core search terms: (taxane or taxol or paclitaxel or docetaxel or Albumin-Bound or Protein-Bound) and (outcomes or "overall survival" or OS or "Progression Free Survival" or PFS) and ("Multidrug Resistance Gene" or ABCB1 or MDR1). We conducted a manual search of the reference lists of retrieved studies or relevant reviews to identify additional published studies. To identify unpublished literature, databases of abstracts were searched, and the authors were contacted. Only the most recent study was included when overlap occurred between studies.

Studies were considered eligible if they fulfilled all of the following criteria: participants: all included patients were diagnosed with Solid tumor; intervention: all included patients were administered taxane-based chemotherapy; control: all studies included comparisons of different categories of the polymorphic genotypes $A B C B 1$ C3435T and C1236T; outcomes: all studies reported the OS and PFS of patients with different genotypes, and studies with enough genotype data to estimate the hazard ratio $(\mathrm{HR})$ and $95 \%$ confidence interval $(\mathrm{Cl})$ in at least one genetic comparison model. The study selection process was performed by 2 authors independently; a third author determined the final criteria for any inconsistencies.

\subsection{Data collection and quality assessment}

Two authors were responsible for extracting the data from eligible studies using a standardized data extraction table. Disagreements were resolved by group discussion or a third author if a consensus could not be reached. Information on the first author's name, publication year, country, patient mean age, sample size, tumor type, regimen, detection, Hardy-Weinberg equilibrium, PFS, and OS for each category of genotypes was collected. Bias caused by individual studies was examined by 2 authors independently according to the Newcastle-Ottawa Scale score, which is useful for comprehensively evaluating the quality of observational studies in meta-analysis. The bias of selection (4 items), comparability ( 1 item), and outcome ( 3 items) were assessed during this process.

\subsection{Data synthesis and analysis}

Three genetic models were analyzed for each gene site in this meta-analysis: homozygote model (TT vs. CC), heterozygote model (CT vs. CC), and dominant model (CT + TT vs. CC). For time to event survival analysis, we assessed the effect of ABCB1 status on patient prognosis by calculating the hazard ratio (HR). For each study, the HR and its $95 \%$ confidence interval $(\mathrm{Cl})$ were retrieved. If these parameters were not available in the studies, we used the software Engauge Digitizer 4.1 to extract specific survival rates according to Kaplan-Meier curves to calculate the HR as described by Tierney et al. [26]. Heterogeneity in the pooled analyses was determined by statistical analyses using the $Q$ statistic for homogeneity and the $\mathrm{I}^{2}$ statistic. A P value of $<0.10$ or $\mathrm{I}^{2}>50 \%$ was considered to indicate significant heterogeneity [27]. When statistical heterogeneity existed, the random-effects model was used; otherwise the fixed effects model was applied. Sensitivity analyses were performed to evaluate the influence of single studies on overall analysis. Subgroup analyses, including area (Asia, Europe, and others), tumor types (ovary, breast, lung, and others), and regimen (paclitaxel plus cisplatin (TP) and others) were conducted. Publication biases were estimated by 
using Egger tests [28]. A two-sided $\mathrm{P}$ value of less than 0.05 was regarded as statistically significant. All statistical analyses were performed using $\mathrm{R}$ version 3.6.1 software.

\section{Results}

\subsection{Search results}

Figure 1 presents the whole process of study selection. A total of 1008 potentially relevant articles were identified by systematic searching of electronic databases and manual searching. After reviewing the titles or abstracts, 235 studies were excluded as duplicates, leaving 773 articles for further title and abstract review. A total of 77 studies were discarded following review of the full text. Fifteen studies were finally identified and included in the analysis. The remaining studies were excluded because of incomparable data, nonrelevant genotypes, and focus on other outcomes $[1,2,4,19-21,23,29-36]$.

\subsection{Study characteristics}

The characteristics of all included studies are listed in Table 1. Fifteen studies reporting data from 3320 patients who were administered taxane-containing chemotherapy were included in this study. These articles were all published in English, and the years of publication ranged from 2008 to 2018 . The sample size ranged from 43 to 511 patients and their mean age ranged from 46 to 65 years. Further, Table 1 shows information on the country, sample sizes, tumor types, regimens, detection, and Newcastle-Ottawa Scale score. Study quality was assessed using the NewcastleOttawa Scale score: 1 study had a score 6, 11 studies had a score of 8, and the remaining 5 studies had a score of 9.

\subsection{ABCB1 C3435T}

\subsubsection{PFS}

Eleven studies involving 2670 patients were included in the meta-analysis of PFS (Fig. 2). The C3435T polymorphism and PFS showed no correlation. Subgroup analysis was performed to evaluate different areas, tumor types, and regimens. The results showed that the CC genotype had a predictive effect on OS (HR 0.69; 95\% Cl: 0.48-0.97) in Europe compared to TT carriers. Ovarian cancer patients who were CC carriers showed a poor PFS (HR 0.74; $95 \%$ Cl: 0.58-0.95) compared to TT carriers. Patients who were CC carriers showed a poor PFS (HR 0.76; 95\% Cl: 0.64-0.91) following TP regimen chemotherapy compared to CT carriers, and a better PFS (HR 1.63; 95\% Cl: 1.02-2.61) following TP regimen chemotherapy compared to TT carriers. Patients who were CT+TT carriers showed a poor PFS (HR 2.17; 95\% Cl: 1.11-4.26) following non-TP regimen chemotherapy compared to CC carriers. Significant heterogeneities were found in the overall meta-analysis of the homozygote model $\left(I^{2}=53 \%, P=0.04\right)$ and dominant model $\left(I^{2}=76 \%, P=0.04\right)$. Sensitivity analyses showed that heterogeneity was decreased in the heterozygous model $\left(I^{2}=12 \%, P=0.34\right)$ after excluding the study by Li et al. [21].

\subsubsection{OS}

Nine studies involving 2255 patients were included in the meta-analysis of OS (Fig. 3). The C3435T polymorphism were not associated with an OS improvement in patients treated with taxane-containing chemotherapy. The results of subgroup analysis showed that European patients who were CC carriers had a poor OS (HR 0.56; 95\% Cl: 0.37-0.85) compared to TT carriers. Ovarian cancer patients who were CC carriers showed a poor OS (HR 0.68; 95\% Cl: 0.470.99) compared to TT carriers. Significant heterogeneities were found in the overall meta-analysis of the homozygote model $\left(I^{2}=56 \%, P=0.03\right)$ and dominant model $\left(I^{2}=53 \%, P=0.03\right)$. Sensitivity analyses showed that heterogeneity 
was decreased in the heterozygous model $\left(\mathrm{I}^{2}=30 \%, \mathrm{P}=0.21\right)$ after excluding the study by $\mathrm{Li}$ et al. and in the dominant model $\left(I^{2}=7 \%, P=0.0 .37\right)$ after excluding the study by Bjorn et al. (Arm A) [1].

\subsection{ABCB1 C1236T}

\subsubsection{PFS}

Seven studies involving 1943 patients were included in the meta-analysis of PFS (Fig. 4). The summary results showed that the effect of the C1236T polymorphism on PFS remained significant in the heterozygote model (HR 0.81; 95\% Cl: 0.67-0.98) and homozygote model (HR 0.71; 95\% Cl: 0.58-0.88). Significant heterogeneities were found in the dominant model $\left(I^{2}=60 \%, P=0.03\right)$. Sensitivity analyses showed that heterogeneity was decreased in the dominant model $\left(I^{2}=41 \%, P=0.15\right)$ after excluding the study by Johnatty et al. [2].

\subsubsection{OS}

Six studies with 1217 patients were included in the meta-analysis of OS (Fig. 4). The CC genotype showed a predictive effect on OS. Compared to the TT phenotype, the CC genotype was associated with a poor OS (HR 0.72; 95\% Cl: 0.530.97). There was heterogeneity among studies.

\section{Publication bias}

No significant publication bias was observed.

\section{Discussion}

This is the first meta-analysis to investigate the role of $A B C B 1$ in patients administered taxane-containing chemotherapy. This comprehensive quantitative study included 3320 patients from 15 studies with a broad range of characteristics. The rs1045642 and rs1128503 polymorphisms are the most extensively studied SNPs in the ABCB1 gene. The summary results from this study indicated that C3435T polymorphisms did not affect PFS and OS; in contrast, subgroup analysis showed that the geographical area, tumor type, and treatment regimen were associated with the PFS and OS. This is consistent with the results of two previous multicenter studies in the United States and Japan. A meta-analysis reported by Jiang revealed that the rs1045642 and rs1128503 polymorphisms were not related to the response to chemotherapy [37]. Although heterogeneities were found in the overall analyses of PFS and OS in the C3435T homozygote and dominant models, we conducted subgroup analysis and identified the geographical area, tumor type, and chemotherapy regimen as the three main sources of heterogeneity between studies.

There are differences in the genetic and biological characteristics, clinical progression pattern, therapeutic responses, and prognoses among different tumor types; the distribution of paclitaxel in different tumors is also different [38]. Sensitivity analysis revealed that the study by Li et al. [21] was a source of statistical heterogeneity. When this outlier study was removed, there was no evidence of heterogeneity in the four remaining studies in the C3435T homozygote model. This may be because Li et al. enrolled patients with breast cancer, which differs from the patient groups in other studies. Therefore, it is important to separately analyze the relationship between $A B C B 1$ and prognosis for different tumor types. Our study showed that in patients with ovarian cancer, being a C3435T TT carrier had predictive value, as these patients had better OS and PFS. Wang et al. showed that the rs 1045642 wild-type allele translates Pgp mRNA better, producing significantly higher mRNA levels [39], whereas patients with homozygous variants of C3435T exhibited reduced P-gp expression [16]. Penson et al. reported that patients with ovarian cancer with high 
expression of P-gp had a short survival time and poor prognosis. $A B C B 1$ gene polymorphisms have different effects on the activities of different chemotherapeutic drugs, and the chemotherapy response and prognosis following administration of different regimens vary widely [40]. Studies have shown that $A B C B 1$ polymorphisms are related to the response to platinum-based chemotherapy [41, 42]. Considering TP as a first-line chemotherapy regimen and platinum as a substrate of $A B C B 1$, inconsistent effects may be observed when the chemotherapy regimen involves TP. Our study showed that TT carriers exhibited conflicting outcomes among patients treated with different regimens. Additionally, the level of medical care and medical resources in different regions is inconsistent, which affects the prognosis of patients [43].

Our study demonstrated the predictive value of $A B C B 1 \mathrm{C} 1236 \mathrm{~T}$ for the PFS and OS in patients who were administered taxane-contained chemotherapy, which is consistent with the results reported by Bjorn et al. [1] and Zhou et al. [44]. The effect of genetic variation on prognosis may be related to mutations that cause changes in the encoded amino acids, affecting the normal function of certain drug transporters, such as decreased expression of P-gp. This can lead to a change in the pharmacokinetics of a drug, decreased levels of drug pumped out of the cell, and then accumulation of the drug in the cell, which may adversely affect therapeutic efficacy [18]. Bosch et al. reported that the C1236T homozygous mutant decreased the clearance of docetaxel, leading to an increase in the area under the curve [45]. The C1236T polymorphism may indirectly affect the stability of the mRNA [46]. Shen et al. [47] suggested that allele-specific differences in RNA folding influence downstream mRNA splicing, processing, or translational control and regulation. Reduced translational activity may also occur.

There are some limitations to this study. The adjusted factors of the extracted data on survival time differed among the included studies, which may have affected the results for disease progression and death. Additionally, subgroup analyses based on other baseline characteristics of patients were not conducted because they were not available in the included studies. The composite effect with other clinical factors and gene variants, such as G2677T/A, was not evaluated because of the present data status. Despite these limitations, our meta-analysis showed that the precision of the estimation was improved by integrating multiple data sets and enlarging the sample size. Additionally, we found no publication bias, supporting the results of our meta-analysis.

\section{Conclusions}

In conclusion, our study suggests a predictive role of $A B C B 1$ polymorphisms in the survival of patients undergoing taxane chemotherapy. $T$ gene carriers have a greater survival benefit. These results provide preliminary evidence of a correlation between the prognosis of patients with cancer and different geographical regions, tumor types, and chemotherapy regimens. Additional large-scale, prospective studies are needed to evaluate the relationship between

other factors such as specific populations, tumors, G2677T/A polymorphisms, and clinical cancer prognosis to ensure more accurate and robust conclusions.

\section{Abbreviations}

ABCB1 adenosine triphosphate binding cassette transporter B subfamily member 1

AUC area under the curve

HR hazard ratio

MDR1 multidrug resistance gene 1 
PFS progression-free survival

P-gp P-glycoprotein

SNPs single nucleotide polymorphisms

TP paclitaxel plus cisplatin

\section{Declarations}

\section{Acknowledgments}

Not applicable.

\section{Funding}

This study was supported by Youth Project from the Fujian Provincial Health Commission (No. 2019-2-53).

\section{Availability of data and materials}

The datasets generated during and/or analyzed during the current study are available from the corresponding author on reasonable request.

\section{Authors' contributions}

CQY and CY made substantial contributions to the study design. CQY, YJH, LM, and LXX screened papers and conducted the quality rating and meta-analysis. Statistical analyses were conducted by CQY and HJF. CQY and LWL were involved in drafting the manuscript. WYY and GJJ were involved in critically revising the manuscript. All authors read and approved the final manuscript.

\section{Ethics approval and consent to participate}

Not applicable.

\section{Consent for publication}

Not applicable.

\section{Competing interests}

The authors declare that they have no competing interests.

\section{References}

1. Bjorn N, Jakobsen Falk I. ABCB1 Variation Affects Myelosuppression, Progression-free Survival and Overall Survival in Paclitaxel/Carboplatin-treated Ovarian Cancer Patients. 2018;123(3):277-87.

2. Johnatty SE, Beesley J, Gao B, Chen X, Lu Y, Law MH, et al. ABCB1 (MDR1) polymorphisms and ovarian cancer progression and survival: $A$ comprehensive analysis from the Ovarian Cancer Association Consortium and the Cancer Genome Atlas. Gynecologic Oncology. 2013;131(1):8-14. 
3. Karageorgopoulou S, Kostakis ID, Gazouli M, Markaki S, Papadimitriou M, Bournakis E, et al. Prognostic and predictive factors in patients with metastatic or recurrent cervical cancer treated with platinum-based chemotherapy. BMC Cancer. 2017;17(1).

4. Szczyrek M, Mlak R, Krawczyk P, Wojas-Krawczyk K, Powrozek T, Szudy-Szczyrek A, et al. Polymorphisms of Genes Encoding Multidrug Resistance Proteins as a Predictive Factor for Second-Line Docetaxel Therapy in Advanced Non-small Cell Lung Cancer. Pathol Oncol Res. 2017;23(3):607-14.

5. Leschziner GD, Andrew T, Pirmohamed M, Johnson MR. ABCB1 genotype and PGP expression, function and therapeutic drug response: a critical review and recommendations for future research. Pharmacogenomics J. 2007;7(3):154-79.

6. Auner V, Sehouli J, Oskay-Oezcelik G, Horvat R, Speiser P, Zeillinger R. ABC transporter gene expression in benign and malignant ovarian tissue. Gynecol Oncol. 2010;117(2):198-201.

7. Dean M, Rzhetsky A, Allikmets R. The human ATP-binding cassette (ABC) transporter superfamily. Genome Res. 2001;11(7):1156-66.

8. Kelland L. The resurgence of platinum-based cancer chemotherapy. Nat Rev Cancer. 2007;7(8):573-84.

9. Genovese I, Ilari A, Assaraf YG, Fazi F, Colotti G. Not only P-glycoprotein: Amplification of the ABCB1-containing chromosome region 7q21 confers multidrug resistance upon cancer cells by coordinated overexpression of an assortment of resistance-related proteins. Drug Resist Updat. 2017;32:23-46.

10. Kim RB, Leake BF, Choo EF, Dresser GK, Kubba SV, Schwarz UI, et al. Identification of functionally variant MDR1 alleles among European Americans and African Americans. Clin Pharmacol Ther. 2001;70(2):189-99.

11. Orina JN, Calcagno AM, Wu CP, Varma S, Shih J, Lin M, et al. Evaluation of current methods used to analyze the expression profiles of ATP-binding cassette transporters yields an improved drug-discovery database. Mol Cancer Ther. 2009;8(7):2057-66.

12. Liu KJ, He JH, Su XD, Sim HM, Xie JD, Chen XG, et al. Saracatinib (AZD0530) is a potent modulator of ABCB1mediated multidrug resistance in vitro and in vivo. Int J Cancer. 2013;132(1):224-35.

13. Xia YZ, Yang L, Xue GM, Zhang C, Guo C, Yang YW, et al. Combining GRP78 suppression and MK2206-induced Akt inhibition decreases doxorubicin-induced P-glycoprotein expression and mitigates chemoresistance in human osteosarcoma. Oncotarget. 2016;7(35):56371-82.

14. De ludicibus S, De Pellegrin A, Stocco G, Bartoli F, Bussani R, Decorti G. ABCB1 gene polymorphisms and expression of P-glycoprotein and long-term prognosis in colorectal cancer. Anticancer Res. 2008;28(6B):3921-8.

15. Hitzl M, Drescher S, van der Kuip H, Schaffeler E, Fischer J, Schwab M, et al. The C3435T mutation in the human MDR1 gene is associated with altered efflux of the P-glycoprotein substrate rhodamine 123 from CD 56+ natural killer cells. Pharmacogenetics. 2001;11(4):293-8.

16. Hoffmeyer S, Burk O, von Richter O, Arnold HP, Brockmoller J, Johne A, et al. Functional polymorphisms of the human multidrug-resistance gene: multiple sequence variations and correlation of one allele with P-glycoprotein expression and activity in vivo. Proc Natl Acad Sci U S A. 2000;97(7):3473-8.

17. Schaich M, Kestel L, Pfirrmann M, Robel K, IIImer T, Kramer M, et al. A MDR1 (ABCB1) gene single nucleotide polymorphism predicts outcome of temozolomide treatment in glioblastoma patients. Ann Oncol. 2009;20(1):175-81.

18. Mizuno N, Niwa T, Yotsumoto Y, Sugiyama Y. Impact of drug transporter studies on drug discovery and development. Pharmacol Rev. 2003;55(3):425-61.

19. Bergmann TK, Green H, Brasch-Andersen C, Mirza MR, Herrstedt J, Holund B, et al. Retrospective study of the impact of pharmacogenetic variants on paclitaxel toxicity and survival in patients with ovarian cancer. Eur $\mathrm{J}$ Clin 
Pharmacol. 2011;67(7):693-700.

20. Grau JJ, Caballero M, Campayo M, Jansa S, Vargas M, Alos L, Monzo M. Gene single nucleotide polymorphism accumulation improves survival in advanced head and neck cancer patients treated with weekly paclitaxel. Laryngoscope. 2009;119(8):1484-90.

21. Li W, Zhang D, Du F, Xing X, Wu Y, Xiao D, et al. ABCB1 3435TT and ABCG2 421CC genotypes were significantly associated with longer progression-free survival in Chinese breast cancer patients. Oncotarget. 2017;8(67):111041-52.

22. Priyadarshini R, Raj GM, Kayal S, Ramesh A, Shewade DG. Influence of ABCB1 C3435T and C1236T gene polymorphisms on tumour response to docetaxel-based neo-adjuvant chemotherapy in locally advanced breast cancer patients of South India. J Clin Pharm Ther. 2019;44(2):188-96.

23. Qiao R, Wu W, Lu D, Han B. Influence of single nucleotide polymorphisms in ABCB1, ABCG2 and ABCC2 on clinical outcomes to paclitaxel-platinum chemotherapy in patients with non-small-cell lung cancer. International Journal of Clinical and Experimental Medicine. 2016;9(1):298-307.

24. Zhong J, Guo Z, Fan L, Zhao X, Zhao B, Cao Z, et al. ABCB1 polymorphism predicts the toxicity and clinical outcome of lung cancer patients with taxane-based chemotherapy. Thorac Cancer. 2019;10(11):2088-95.

25. Stroup DF, Berlin JA, Morton SC, Olkin I, Williamson GD, Rennie D, et al. Meta-analysis of observational studies in epidemiology: a proposal for reporting. Meta-analysis Of Observational Studies in Epidemiology (MOOSE) group. JAMA. 2000;283(15):2008-12.

26. Tierney JF, Stewart LA, Ghersi D, Burdett S, Sydes MR. Practical methods for incorporating summary time-to-event data into meta-analysis. Trials. 2007;8:16.

27. Higgins JP, Thompson SG, Deeks JJ, Altman DG. Measuring inconsistency in meta-analyses. BMJ. 2003;327(7414):557-60.

28. Egger M, Davey Smith G, Schneider M, Minder C. Bias in meta-analysis detected by a simple, graphical test. BMJ. 1997;315(7109):629-34.

29. Chang H, Rha SY, Jeung HC, Im CK, Ahn JB, Kwon WS, et al. Association of the ABCB1 gene polymorphisms $2677 \mathrm{G}>\mathrm{T} / \mathrm{A}$ and $3435 \mathrm{C}>\mathrm{T}$ with clinical outcomes of paclitaxel monotherapy in metastatic breast cancer patients. Annals of Oncology. 2009;20(2):272-7.

30. Chang H, Rha SY, Jeung HC, Im CK, Noh SH, Kim JJ, Chung HC. Association of the ABCB1 3435C>T polymorphism and treatment outcomes in advanced gastric cancer patients treated with paclitaxel-based chemotherapy. Oncology Reports. 2010;23(1):271-8.

31. Gandara DR, Kawaguchi T, Crowley J, Moon J, Furuse K, Kawahara M, et al. Japanese-US common-arm analysis of paclitaxel plus carboplatin in advanced non-small-cell lung cancer: a model for assessing population-related pharmacogenomics. Journal of clinical oncology. 2009;27(21):3540-6.

32. Johnatty SE, Beesley J, Paul J, Fereday S, Spurdle AB, P Mw, et al. ABCB1 (MDR 1) polymorphisms and progression-free survival among women with ovarian cancer following paclitaxel/carboplatin chemotherapy. Clinical Cancer Research. 2008;14(17):5594-601.

33. Kim JW, Kim JH, Im SA, Kim YJ, Han HS, Kim JS, et al. ABCB1, FCGR2A, and FCGR3A polymorphisms in patients with HER2-positive metastatic breast cancer who were treated with first-line taxane plus trastuzumab chemotherapy. Oncology (Switzerland). 2012;83(4):218-27.

34. Peethambaram P, Fridley BL, Vierkant RA, Larson MC, Kalli KR, Elliott EA, et al. Polymorphisms in ABCB1 and ERCC2 associated with ovarian cancer outcome. International Journal of Molecular Epidemiology and Genetics. 2011;2(2):185-95. 
35. Shim HJ, Yun JY, Hwang JE, Bae WK, Cho SH, Lee JH, et al. BRCA1 and XRCC1 polymorphisms associated with survival in advanced gastric cancer treated with taxane and cisplatin. Cancer Science. 2010;101(5):1247-54.

36. Tian C, Ambrosone CB, Darcy KM, Krivak TC, Armstrong DK, Bookman MA, et al. Common variants in ABCB1, $A B C C 2$ and $A B C G 2$ genes and clinical outcomes among women with advanced stage ovarian cancer treated with platinum and taxane-based chemotherapy: A Gynecologic Oncology Group study. Gynecologic Oncology. 2012;124(3):575-81.

37. Jiang Q, Xu M, Liu Y, Chen Y, Feng J, Wang X, et al. Influence of the ABCB1 polymorphisms on the response to Taxane-containing chemotherapy: a systematic review and meta-analysis. Cancer Chemother Pharmacol. 2018;81(2):315-23.

38. Giordano S, Zucchetti M, Decio A, Cesca M, Fuso Nerini I, Maiezza M, et al. Heterogeneity of paclitaxel distribution in different tumor models assessed by MALDI mass spectrometry imaging. Sci Rep. 2016;6:39284.

39. Wang D, Johnson AD, Papp AC, Kroetz DL, Sadee W. Multidrug resistance polypeptide 1 (MDR1, ABCB1) variant 3435C>T affects mRNA stability. Pharmacogenet Genomics. 2005;15(10):693-704.

40. Binkhathlan Z, Lavasanifar A. P-glycoprotein inhibition as a therapeutic approach for overcoming multidrug resistance in cancer: current status and future perspectives. Curr Cancer Drug Targets. 2013;13(3):326-46.

41. Sun S, Cai J, Yang Q, Zhu Y, Zhao S, Wang Z. Prognostic Value and Implication for Chemotherapy Treatment of ABCB1 in Epithelial Ovarian Cancer: A Meta-Analysis. PLoS One. 2016;11(11):e0166058.

42. Zhang Z, Xiang Q, Mu G, Xie Q, Chen S, Zhou S, et al. XRCC1 polymorphism and overall survival in ovarian cancer patients treated with platinum-based chemotherapy: A systematic review and MOOSE-compliant meta-analysis. Medicine (Baltimore). 2018;97(45):e12996.

43. Bray F, Ferlay J, Soerjomataram I, Siegel RL, Torre LA, Jemal A. Global cancer statistics 2018: GLOBOCAN estimates of incidence and mortality worldwide for 36 cancers in 185 countries. CA Cancer J Clin.

2018;68(6):394-424.

44. Zhou Z, Chen Q, Zuo D, Wang H, Hua Y, Cai Z. ABCB1 (rs1128503) polymorphism and response to chemotherapy in patients with malignant tumors-evidences from a meta-analysis. Int J Clin Exp Med. 2015;8(1):265-72.

45. Bosch TM, Huitema AD, Doodeman VD, Jansen R, Witteveen E, Smit WM, et al. Pharmacogenetic screening of CYP3A and ABCB1 in relation to population pharmacokinetics of docetaxel. Clin Cancer Res. 2006;12(19):578693.

46. Frittitta L, Ercolino T, Bozzali M, Argiolas A, Graci S, Santagati MG, et al. A cluster of three single nucleotide polymorphisms in the 3'-untranslated region of human glycoprotein PC-1 gene stabilizes PC-1 mRNA and is associated with increased PC-1 protein content and insulin resistance-related abnormalities. Diabetes. 2001;50(8):1952-5.

47. Shen LX, Basilion JP, Stanton VP, Jr. Single-nucleotide polymorphisms can cause different structural folds of mRNA. Proc Natl Acad Sci U S A. 1999;96(14):7871-6.

\section{Table 1}

\section{Table1. Baseline characteristics of the studies included in the meta-analysis}




\begin{tabular}{|c|c|c|c|c|c|c|c|c|c|}
\hline Study & Country & $\begin{array}{c}\text { Size } \\
M / F(n) \\
\text { Age }\end{array}$ & $\begin{array}{l}\text { Tumor } \\
\text { type }\end{array}$ & Regimen (Dose) & Detection & HWE & $\begin{array}{l}\text { End- } \\
\text { point }\end{array}$ & Gene & NOS \\
\hline $\begin{array}{l}\text { Bergamnn } \\
2011\end{array}$ & $\begin{array}{l}\text { Denmark/ } \\
\text { Sweden }\end{array}$ & $\begin{array}{c}119 \\
\text { N/A } \\
57 \\
(26- \\
77)\end{array}$ & Ovary & $\begin{array}{l}\text { TP }\left(175 \mathrm{mg} / \mathrm{m}^{2} \text { and }\right. \\
\text { AUC5-6) }\end{array}$ & Pyrosequencing & $\mathrm{P} \square 0.05$ & $\mathrm{OS}$ & C3435T & 8 \\
\hline $\begin{array}{l}\text { Bjorn } \\
\text { (Arm A) } \\
2018\end{array}$ & Sweden & $\begin{array}{c}260 \\
\text { N/A } \\
56(26- \\
81)\end{array}$ & Ovary & $\begin{array}{l}\text { TP }\left(250 \mathrm{mg} / \mathrm{m}^{2} \text { and }\right. \\
\text { AUC5-6) }\end{array}$ & Pyrosequencing & $\mathrm{P} \square 0.05$ & $\mathrm{PFS} / \mathrm{OS}$ & $\begin{array}{l}\text { C3435T } \\
\text { C1236T }\end{array}$ & 8 \\
\hline $\begin{array}{l}\text { Bjorn } \\
\text { (Arm B) } \\
2018\end{array}$ & Sweden & $\begin{array}{c}265 \\
\text { N/A } \\
56(37- \\
81)\end{array}$ & Ovary & $\begin{array}{l}\text { TP }\left(175 \mathrm{mg} / \mathrm{m}^{2} \text { and }\right. \\
\text { AUC5-6) }\end{array}$ & Pyrosequencing & $\mathrm{P} \square 0.05$ & $\mathrm{PFS} / \mathrm{OS}$ & $\begin{array}{l}\text { C3435T } \\
\text { C1236T }\end{array}$ & 8 \\
\hline $\begin{array}{l}\text { Chang } \\
2009\end{array}$ & Korea & $\begin{array}{c}108 \\
\text { N/A } \\
49 \\
(32- \\
71)\end{array}$ & Breast & Paclitaxel $\left(175 \mathrm{mg} / \mathrm{m}^{2}\right)$ & Sanger & $\mathrm{P} \square 0.05$ & OS & C3435T & 8 \\
\hline $\begin{array}{l}\text { Chang } \\
2010\end{array}$ & Korea & $\begin{array}{c}43 \\
26 / 17 \\
47(23- \\
68)\end{array}$ & Gastric & $\begin{array}{l}\text { Paclitaxel }\left(175 \mathrm{mg} / \mathrm{m}^{2}\right) \\
+ \\
\text { Leucovorin }\left(20 \mathrm{mg} / \mathrm{m}^{2}\right) \\
+ \\
5 \text {-fluorouracil }(1000 \\
\left.\mathrm{mg} / \mathrm{m}^{2}\right)\end{array}$ & Sanger & Pप0.05 & PFS & C3435T & 6 \\
\hline $\begin{array}{l}\text { Gandara } \\
2009\end{array}$ & American & $\begin{array}{c}197 \\
136 / 61 \\
65 \\
(33- \\
81) \\
184 \\
116 / 68 \\
63 \\
(28- \\
80)\end{array}$ & Lung & $\begin{array}{l}\mathrm{TP}\left(225 \mathrm{mg} / \mathrm{m}^{2} \text { and }\right. \\
\text { AUC6) }\end{array}$ & Pyrosequencing & $\mathrm{P} \square 0.05$ & $\mathrm{PFS} / \mathrm{OS}$ & C3435T & 8 \\
\hline $\begin{array}{l}\text { Grau } \\
2009\end{array}$ & Spain & $\begin{array}{c}47 \\
43 / 4 \\
57 \\
(46- \\
80)\end{array}$ & $\begin{array}{l}\text { Head } \\
\text { and } \\
\text { neck }\end{array}$ & Paclitaxel $\left(80 \mathrm{mg} / \mathrm{m}^{2}\right)$ & $\begin{array}{l}\text { Primers and } \\
\text { probes }\end{array}$ & $\mathrm{P} \square 0.05$ & PFS & $\begin{array}{l}\text { C3435T } \\
\text { C1236T }\end{array}$ & 8 \\
\hline $\begin{array}{l}\text { Johnatty } \\
2008\end{array}$ & Austria & $\begin{array}{c}309 \\
\text { N/A } \\
58(31- \\
80)\end{array}$ & Ovary & $\begin{array}{l}\text { TP } \\
\left(175 \text { or } 135 \mathrm{mg} / \mathrm{m}^{2} \text { and }\right. \\
\text { AUC5-6) }\end{array}$ & MALDI-TOF & $\mathrm{P} \square 0.05$ & $\mathrm{PFS} / \mathrm{OS}$ & $\begin{array}{l}\text { C3435T } \\
\text { C1236T }\end{array}$ & 9 \\
\hline $\begin{array}{l}\text { Johnatty } \\
2013\end{array}$ & Austria & $\begin{array}{l}433 \\
\text { N/A } \\
\text { N/A }\end{array}$ & Ovary & $\begin{array}{l}\text { TP } \\
\left(175 \text { or } 135 \mathrm{mg} / \mathrm{m}^{2} \text { and }\right. \\
\text { AUC5-6) }\end{array}$ & $\begin{array}{c}\text { Illumina } \\
\text { Infinium iSelect } \\
\text { array }\end{array}$ & $P>0.05$ & PFS & $\begin{array}{l}\text { C3435T } \\
\text { C1236T }\end{array}$ & 9 \\
\hline $\begin{array}{c}\text { Kim } \\
2012\end{array}$ & Korea & $\begin{array}{c}57 \\
\text { N/A } \\
46 \\
(27- \\
72)\end{array}$ & Breast & $\begin{array}{l}\text { Paclitaxel +trastuzumab } \\
\left(80 \mathrm{mg} / \mathrm{m}^{2}+\mathrm{load} 4 \mathrm{mg} / \mathrm{kg}\right. \\
\text { maintain } 2 \mathrm{mg} / \mathrm{kg} \\
\text { weekly; } \\
175 \mathrm{mg} / \mathrm{m}^{2}+\text { load } \\
8 \mathrm{mg} / \mathrm{kg} \mathrm{maintain} \\
6 \mathrm{mg} / \mathrm{kg} \text { 3weeks) } \\
\text { Docetaxel } \\
\text { +trastuzumab } \\
75 \mathrm{mg} / \mathrm{m}^{2}+\mathrm{load} 8 \mathrm{mg} / \mathrm{kg} \\
\text { maintain } 6 \mathrm{mg} / \mathrm{kg} \\
\text { 3weeks) }\end{array}$ & PCR-RFLP & $\mathrm{P}>0.05$ & $\mathrm{PFS} / \mathrm{OS}$ & C3435T & 8 \\
\hline $\begin{array}{c}\mathrm{Li} \\
2017\end{array}$ & Chinese & $\begin{array}{c}100 \\
\mathrm{~N} / \mathrm{A} \\
50(23- \\
77)\end{array}$ & Breast & $\begin{array}{l}\text { Docetaxel and } \\
\text { Epirubicin (NA) }\end{array}$ & TaqMan & $P>0.05$ & $\mathrm{PFS} / \mathrm{OS}$ & C3435T & 9 \\
\hline $\begin{array}{c}\text { Prema } \\
2011\end{array}$ & American & $\begin{array}{l}365 \\
\text { N/A } \\
\text { N/A }\end{array}$ & Ovary & $\begin{array}{l}\text { Paclitaxel or Docetaxel } \\
\text { (NA) }\end{array}$ & Veracode Assay & $\mathrm{P}>0.05$ & PFS & C1236T & 9 \\
\hline $\begin{array}{l}\text { Qiao } \\
2016\end{array}$ & Chinese & $\begin{array}{c}64 \\
44 / 20\end{array}$ & Lung & $\begin{array}{l}\text { TP }\left(175 \mathrm{mg} / \mathrm{m}^{2} \text { and }\right. \\
\text { AUC5-6) }\end{array}$ & $\begin{array}{l}\text { Sequenom } \\
\text { iPLEX Mass }\end{array}$ & $\mathrm{P}>0.05$ & $\mathrm{PFS} / \mathrm{OS}$ & $\begin{array}{l}\text { C3435T } \\
\text { C1236T }\end{array}$ & 8 \\
\hline
\end{tabular}




\begin{tabular}{|c|c|c|c|c|c|c|c|c|c|}
\hline & & $\begin{array}{c}58(38- \\
73)\end{array}$ & & & $\begin{array}{l}\text { ARRAY } \\
\text { Platform }\end{array}$ & & & & \\
\hline $\begin{array}{l}\text { Shim } \\
2010\end{array}$ & Korea & $\begin{array}{c}200 \\
150 / 50 \\
58 \\
(19- \\
76)\end{array}$ & Gastric & $\begin{array}{l}\text { TP } \\
\left(175 \mathrm{mg} / \mathrm{m}^{2} \text { and } 75 \mathrm{mg} /\right. \\
\left.\mathrm{m}^{2} \text { cisplatin }\right)\end{array}$ & RFLP & $\mathrm{P}>0.05$ & PFS/OS & $\begin{array}{l}\text { C3435T } \\
\text { C1236T }\end{array}$ & 8 \\
\hline $\begin{array}{c}\text { Szczyrek } \\
2016\end{array}$ & Poland & $\begin{array}{l}58 \\
49 / 9 \\
\text { N/A }\end{array}$ & Lung & Docetaxel $\left(75 \mathrm{mg} / \mathrm{m}^{2}\right)$ & PCR HRM & $\mathrm{P}>0.05$ & OS & C3435T & 8 \\
\hline $\begin{array}{l}\text { Tian } \\
2012\end{array}$ & American & $\begin{array}{l}511 \\
\text { N/A } \\
58 \\
(24- \\
87)\end{array}$ & Ovary & $\begin{array}{l}\text { TP }\left(175 \mathrm{mg} / \mathrm{m}^{2} \text { and }\right. \\
\text { AUC5-6) or } \\
\text { TP }\left(135 \mathrm{mg} / \mathrm{m}^{2} \text { and } 75\right. \\
\left.\mathrm{mg} / \mathrm{m}^{2} \text { cisplatin }\right)\end{array}$ & $\begin{array}{c}\text { Sequenom } \\
\text { iPLEX Mass } \\
\text { ARRAY } \\
\text { Platform and } \\
\text { MALDI-TOF } \\
\text { Mass } \\
\text { Spectrometry }\end{array}$ & $\mathrm{P}>0.05$ & PFS/OS & C3435T & 9 \\
\hline
\end{tabular}

\section{Figures}

Records identified through database searching $(\mathrm{n}=1008)$

\section{Additional records identified}

through other sources $(n=0)$

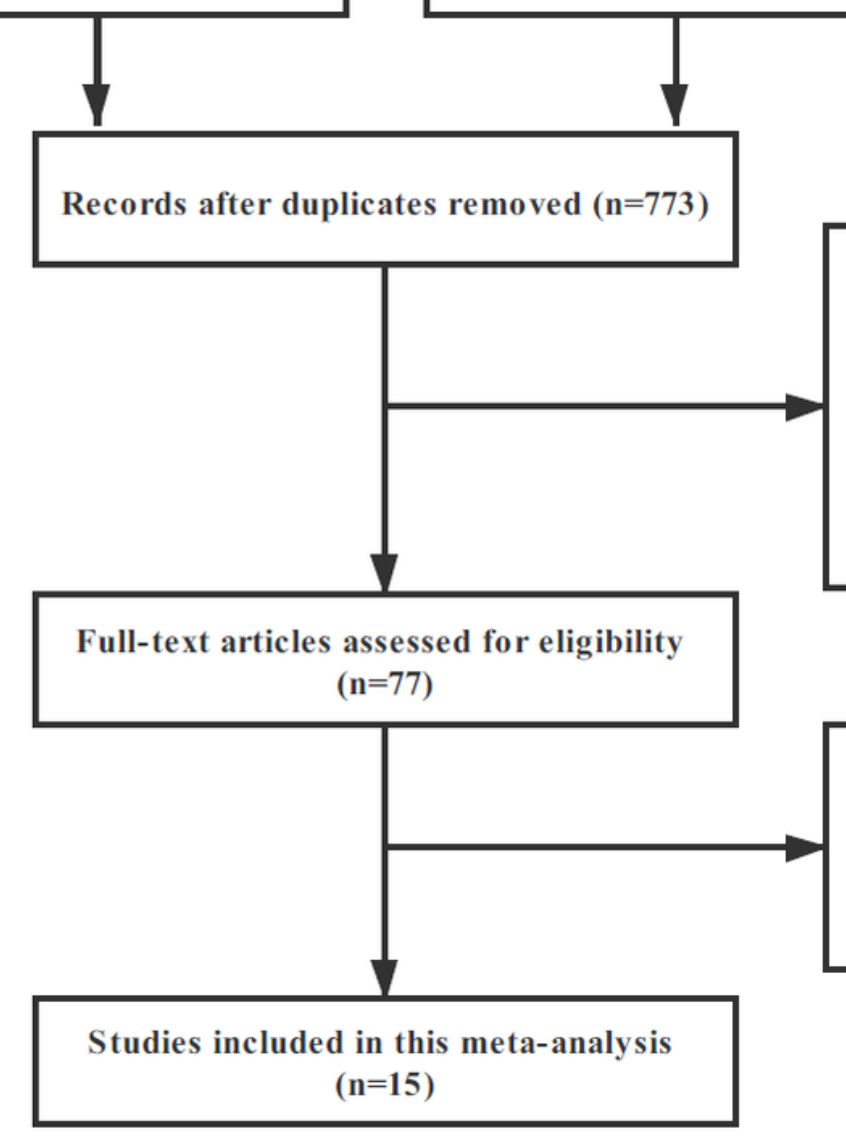

696 studies were excluded by reading title or abstract Animal (48)

Cell, molecule or protein (311)

Review (118)

Other drugs (13)

Pharmacokinetics (11)

Irrelevant studies (195)

62 studies were excluded after review of full text

Reported other outcomes $(n=51)$

Did not provide sufficient date $(n=6)$

Reported other genetic $(n=5)$

\section{Figure 1}

Flow diagram of the literature search and trial selection process. 


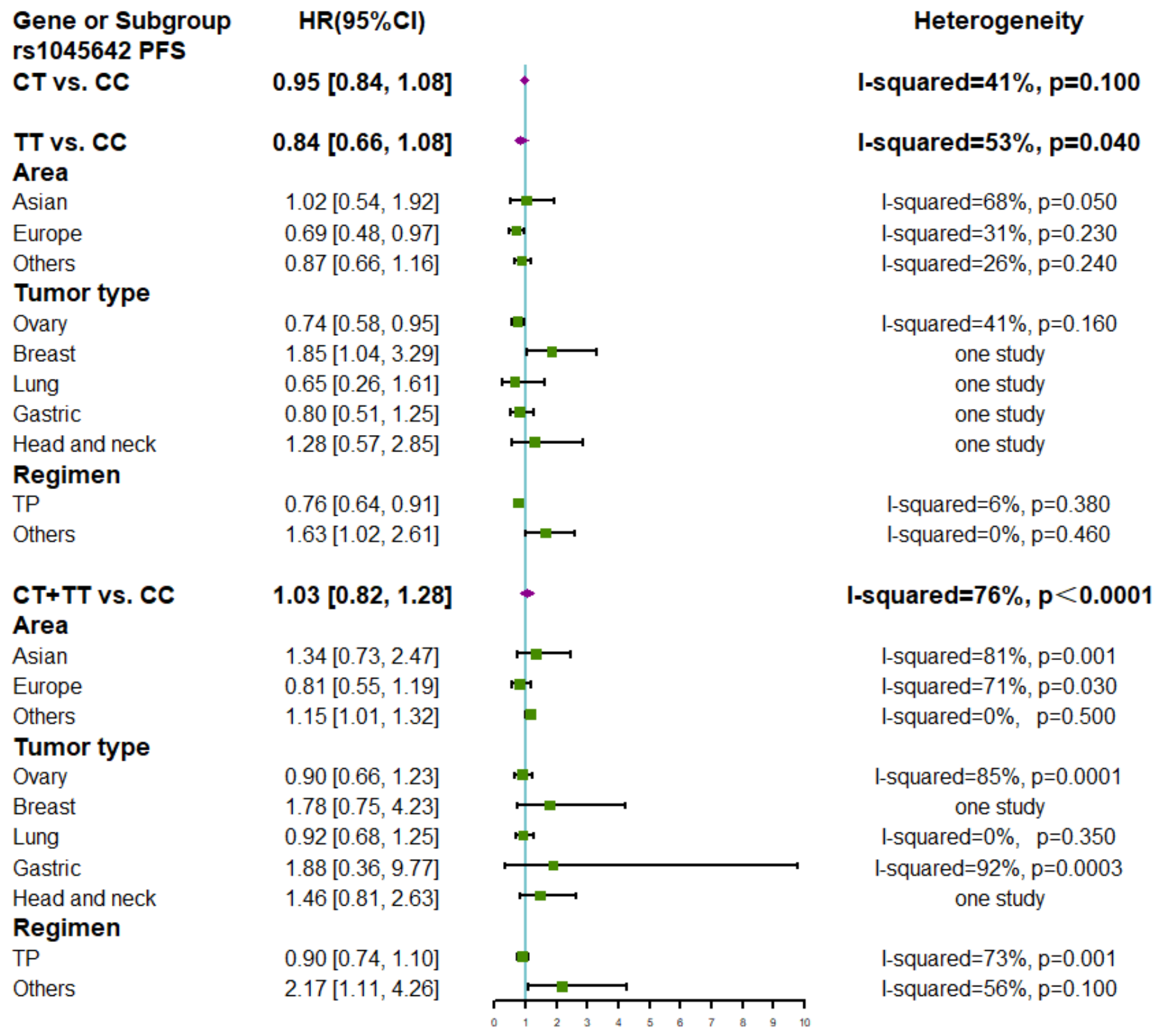

Figure 2

Forest plots of ABCB1 rs1045642 polymorphisms and subgroups on progression-free survival of patients administered taxane-based chemotherapy. 


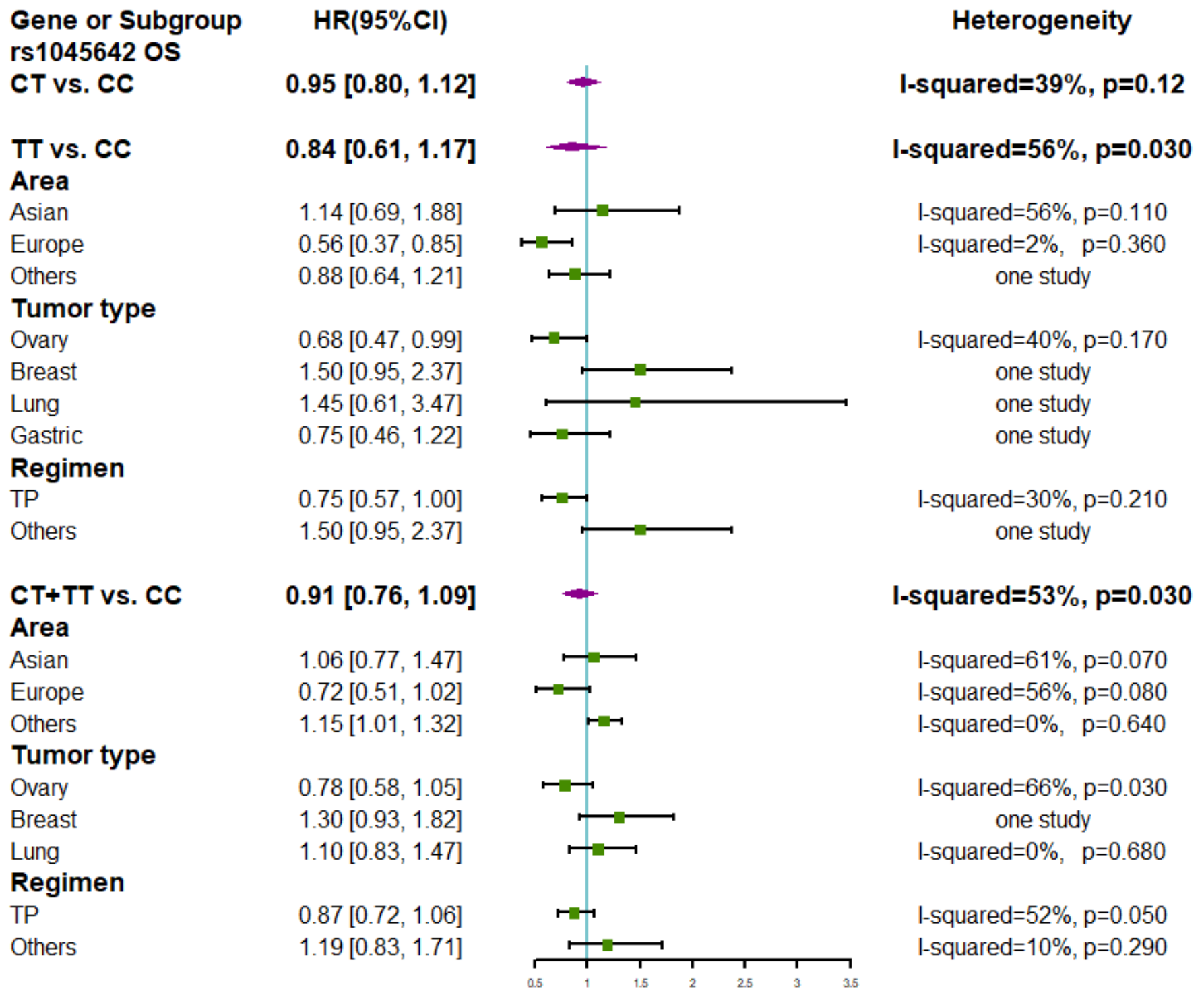

Figure 3

Forest plots of ABCB1 rs1045642 polymorphisms and subgroups for overall survival of patients administered taxanebased chemotherapy. 


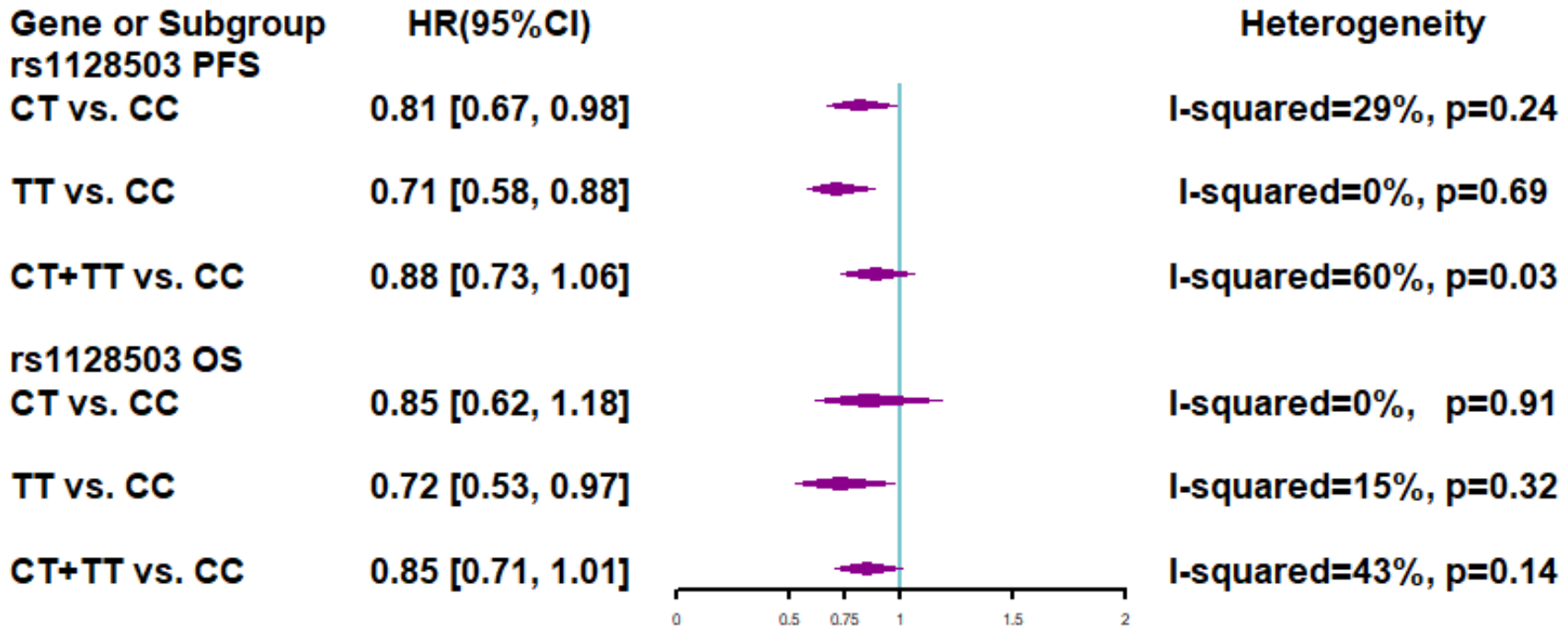

Figure 4

Forest plots of ABCB1 rs1128503 polymorphisms and subgroups for progression-free survival and overall survival of patients administered taxane-based chemotherapy.

\section{Supplementary Files}

This is a list of supplementary files associated with this preprint. Click to download.

- Additionalfile1.pdf

- Additionalfile2.pdf 